\title{
List do UMBERTA Eco \\ (CZYLI JAK URZĄDZIĆ ARCHIWUM PUBLICZNE)
}

Wielce Szanowny Panie Profesorze,

D)o kilkunastu latach po raz kolejny wróciłem do lektury Pańskich felietonów, pośród których moją uwagę przykuł szczególnie tekst zatytułowany Jak urządzić bibliotekę publiczną. Wydaje się, że równie interesujące jak urządzanie biblioteki może być organizowanie archiwum publicznego. Proszę wybaczyć, że w moich przepisach na archiwum wystąpią niekiedy pewne powtórzenia, ale bądź co bądź mamy tutaj do czynienia z instytucjami o zbliżonym profilu działania.

1. „W sytuacji idealnej” użytkownika „powinien obowiązywać zakaz wstępu" do archiwum ${ }^{2}$, ale...

2. Wskazane jest, aby zasób jednego archiwum, nie stosując żadnych sensownych kryteriów, podzielić pomiędzy kilka budynków w jednym mie-

Krzysztof Kopıński - Instytut Historii i Archiwistyki Uniwersytetu Mikołaja Kopernikaw Toruniu, e-mail: kkop@umk.pl. Zainteresowania badawcze: archiwistyka, systemy informacji archiwalnej, edytorstwo źródeł historycznych, historia średniowiecza.

1 U. Eco, Jak urządzić bibliotekę publiczna, [w:] tenże, Zapiski na pudetku od zapatek, przeł. A. Szymanowski, Poznań 1993.

2 Por. tamże, s. 23, pkt 18. 
ście. Jest to zgodne z polityką państwową i oczekiwaniami społecznymi, tzw. wyjściem urzędów do społeczeństwa.

3. Jednoczesnej ewentualnej lokalizacji budynku archiwum na obrzeżach miasta nie wolno korelować z planami rozwoju komunikacji miejskiej, co będzie ważne w przypadku użytkowników przyjezdnych. Za działanie bardzo przezorne i zapobiegliwe należy uznać umiejscawianie budynków archiwów w pobliżu dużych zbiorników wodnych i cieków mogących wylać. Szkody powstałe w wyniku zalania materiałów archiwalnych wytworzonych na terenie byłego zaboru austriackiego pokryje rząd austriacki, szkody powstałe wskutek zalania archiwaliów wytworzonych na terenie byłego zaboru pruskiego zrefinansują z nawiązką zasobne fundacje niemieckie, szkody powstałe w związku z zalaniem dokumentacji wytworzonej na terenie byłego zaboru rosyjskiego pokryją hojni milionerzy rosyjscy oraz GAZPROM.

4. Casus podwórza: niezależnie od zabezpieczenia drzwi wejściowych archiwa mające podwórze powinny ogrodzić się i zainstalować furtę z dzwonkiem lub domofonem. Brama prowadząca na podwórze z parkingiem archiwum winna być zamknięta dla zmotoryzowanych użytkowników.

5. Casus dzwonka lub domofonu: wskazane jest, aby drzwi do furty oraz następnie do budynku archiwum były otwierane dopiero po kilkakrotnym wciśnięciu dzwonka lub domofonu.

6. Casus niczego po wejściu: wskazane jest wypracowanie takiej sytuacji, aby po wejściu do budynku archiwum nie wiadomo było, dokąd pójść dalej.

7. Casus portierni: niewielkie i ciasne okienko portierni archiwum należy umieścić na wysokości $80 \mathrm{~cm}$ (właściwy wzorzec w tym zakresie to kiosk Ruchu), gdyż nasze społeczeństwo cierpi na wady postawy, a skłony pozwolą temu zaradzić.

8. Casus księgi wejść do budynku: księgę umieścić na bardzo wąskiej przestrzeni utrudniającej podpisanie się (o, znowu przyszedł jakiś analfabeta), obok położyć koniecznie rozpadający się długopis.

9. W budynku archiwum nie wolno umieszczać żadnych tablic informacyjnych.

10. Pracownia naukowa oraz sekretariat (kancelaria) winny być lokowane na możliwie jak najwyższej kondygnacji budynku. Do wspomnianych pomieszczeń powinny prowadzić słabo oświetlone, wąskie, kręte i śliskie schody. Dyplomowany archiwista nie może przebywać pod żadnym pozorem w sekretariacie, gdyż mogłoby to nadmiernie usprawnić działanie archiwum. W związku z tym nie jest wskazane, aby jakąkolwiek 
najprostszą sprawę pisemną oraz zapytanie bezpośrednie lub telefoniczne petenta można było szybko załatwić.

11. Dostęp do znajdującej się w archiwum windy dla osób upośledzonych ruchowo, chcących odwiedzić pracownię, winien być utrudniony za pomocą schodów prowadzących do budynku, ciężko otwierających się drzwi budynku oraz schodów prowadzących do miejsca, gdzie jest winda wewnątrz budynku archiwum.

12. W pracowni naukowej nie wolno umieszczać kompletu inwentarzy. Jeżeli już, to należy je zamknąć w szafach mających dobre zamki. Klucze do szaf powinny znaleźć się koniecznie w zamykanej szufladce, do której z kolei klucze są dobrze schowane w sejfie w gabinecie dyrektora, ten zaś ma dobre zamki patentowe.

13. Szczególnie często wykorzystywane inwentarze powinien mieć w swoim pokoju archiwista, który:

a) z racji wykonywanych obowiązków jest zobligowany do częstych wyjść służbowych,

b) co najmniej kilka razy w roku przebywa na długim zwolnieniu chorobowym.

14. Nie należy przesadzać ze szczegółowością pomocy archiwalnych. Przy opracowywaniu materiałów archiwalnych nie trzeba przejmować się i zaglądać do teczek, bo ich zawartość treściową najlepiej odzwierciedlają tytuły na obwolutach. Świadomie należy pominąć informacje istotne, w tym np. dane o planach registratury lub wykazach rzeczowych. A tak w ogóle archiwum to nie jakaś instytucja naukowa, ale urząd!!!

15. W związku z tym wskazane jest, aby jak najwięcej zespołów archiwalnych nie miało żadnej ewidencji.

16. Komputer (koniecznie liczba pojedyncza) z bazami danych udostępniony dla użytkowników w pracowni naukowej powinien być przynajmniej pięcioletni i znacznie wolniejszy od tych będących obecnie powszechnie w użyciu. Rozdzielczość monitora należy ustawić w ten sposób, aby literki w programach z danymi o zasobie archiwalnym były jak najmniejsze. Nie ma potrzeby wykładania w pracowni instrukcji do rzeczonych baz danych i programów. Drukarka pozwalająca na wydruk raportów z archiwalnych aplikacji powinna być zepsuta.

17. Do komputera w pracowni należy podłączyć koniecznie klawiaturę twardą, która jest odpowiednio głośna.

18. Książki z biblioteki podręcznej archiwum, przede wszystkim regionalia znajdujące się w pracowni, służące do badań porównawczych, powinny być dobrze zabezpieczone przed nieograniczonym dostępem. Katalog i zbiory biblioteki podręcznej należy w miarę możliwości trzymać kilka 
kondygnacji nad lub pod pracownią. Część księgozbioru, udostępniona bez rewersów, powinna znaleźć się w pokojach służbowych archiwistów, co pozwoli znacznie skomplikować dotarcie do nich. Ceny za kserokopie z książek winny być takie same jak „zaporowe” ceny za kserokopie z materiałów archiwalnych. Przecież wiadomo, że archiwum to nie biblioteka!!!

19. Kategorycznie zabronione jest korzystanie z więcej niż jednej jednostki archiwalnej jednocześnie, bo jeszcze coś zostanie przełożone. Można również od tego „dostać zeza”.

20. Proces wypożyczania materiałów archiwalnych i mikrofilmów z zewnątrz powinien ze względów „formalnych” trwać maksymalnie długo. Wypożyczenie takie powinno odbywać się tylko na bardzo krótki czas.

21. Edytorom źródeł (osobom przygotowującym edycje źródłowe do druku) zabrać $\mathrm{w}$ trakcie pracy rękopis i przekazać na wielomiesięczną wystawę archiwalną, tudzież do długotrwałej konserwacji.

22. Przywołaną nieopatrznie konserwację materiałów archiwalnych należy stosować rzadko, ale skutecznie, tj. tak, aby obiekt konserwowany po przeprowadzonych zabiegach stawał się nieczytelny. Całkowicie zakazuje się badania w długim czasie stanu archiwaliów poddanych zabiegom konserwatorskim. W ogóle świadomość możliwości przeprowadzenia takich badań zburzyłaby mit o nieomylności konserwatorów, więc nie wolno nawet o tym myśleć. Konserwacja papieru i materiałów ze skóry jest nauką stosunkowo nową, zatem istnieje duża szansa, że „odnowione i zabezpieczone" dokumenty i księgi w miarę szybko się rozpadną.

23. Wybitnym badaczom dziejów kancelarii średniowiecznej i nowożytnej oraz sfragistykom trzeba zawsze proponować udostępnienie mikrofilmów zamiast oryginałów dokumentów i ksiąg. Ewentualne udostępnienie oryginałów powinno odbywać się tylko na podstawie pisemnej zgody dyrektora archiwum po wcześniejszym także pisemnym podaniu tegoż użytkownika.

24. W pracowni powinno być kilka czytników mikrofilmowych. Mantrowy dźwięk przewijanej szpuli „przyspiesza” czytanie materiałów archiwalnych. Efekt zwiększa stosowanie szpul metalowych.

25. Z czytników mikrofilmowych nie należy usuwać kurzu i zanieczyszczeń pozostawionych przez przewijany film.

26. Przepalone lampki w czytnikach mikrofilmowych należy wymieniać raz na kilka miesięcy. Nie powinno zgłaszać się szybko większych awarii czytników w serwisie.

3 Por. tamże, s. 22, pkt 6. 
27. Należy dążyć do takiego ustawienia stołów i krzeseł w pracowni, aby użytkownicy sobie wzajemnie przeszkadzali.

28. Wspomnianych już edytorów źródeł w momencie głośnego sczytywania (kolacjonowania) wydawanego rękopisu posadzić w pracowni naukowej pomiędzy pozostałymi użytkownikami.

29. W pracowni naukowej winien być zainstalowany aparat telefoniczny o bardzo wyraźnym sygnale.

30. Nie wprowadzać zakazu używania telefonów komórkowych.

31. Zawiesić zegar, który głośno bije.

32. Przy komputerze archiwistów w pracowni naukowej winny stać maksymalnie rozkręcone głośniki, a w samym komputerze powinien być ustawiony długi dźwięk startowy.

33. Nie wolno wyciszać drzwi pracowni, żeby użytkownikom przeszkadzały rozmowy prowadzone na korytarzu.

34. Nie uciszać głośno rozmawiających w pracowni.

35. Nie kłaść w pracowni naukowej chodników na podłogę, bo kroki dam w pięknych bucikach na obcasach usłyszą nawet głusi.

36. Pracownia winna być umieszczona w takiej części budynku archiwum, z której po otwarciu okien (lub nawet bez wykonywania tej czynności) słychać gwar dochodzący z ulicy, przechodzące wycieczki i pielgrzymki, defilady wojsk, kataryniarzy, muzyków, pijaków, sprzedawców z pobliskich kramów, szum wody spuszczanej z pobliskiej zapory wodnej, przejeżdżające samochody osobowe, autobusy, tiry i tramwaje.

37. W godzinach funkcjonowania pracowni naukowej powinny być prowadzone w archiwum remonty z wykorzystaniem wiertarek udarowych.

38. Wszelkie prace remontowo-budowlane w archiwum należy intensyfikować wraz ze wzrostem liczby użytkowników w pracowni naukowej.

39. Nie odkurzać zabrudzonych materiałów archiwalnych przed udostępnieniem osobom, które są ubrane w jasne stroje.

40. Zadbać o jak najgorsze ustawienie stołów do światła dziennego.

41. Nie wymieniać przepalonych żarówek w lampach sufitowych oraz w lampkach na biurkach. Z tych ostatnich zresztą można byłoby w ogóle zrezygnować.

42. Parkiet w pracowni należy pomalować najgorszej jakości lakierami, które jeszcze długo potem będą wydzielały przykry zapach. Również użyty do wykładziny klej i sama wykładzina podłogowa w pracowni mogą wydzielać specyficzny odór.

43. Wietrzenie wraz z wyproszeniem użytkowników z pracowni i zdaniem archiwaliów do magazynu podręcznego przeprowadzać jak najczęściej. 
Wszystko odbywa się dla dobra użytkownika, bo istnieje uzasadnione podejrzenie, że kogoś szczupłego mógłby porwać przez okno przewiew.

44. W zimie grzejniki w pracowni powinny być maksymalnie skręcone.

45. Krzesła w pracowni winny uniemożliwiać zajęcie miejsc osobom otyłym.

46. Stoły nie powinny być za duże ze względu na możliwość korzystania z planów i map wielkoformatowych.

47. Informatorium powinno być niedostępne.

48. Kopiowanie technikami nowoczesnymi i alternatywnymi (skanowanie, wykonywanie zdjęć cyfrowych), acz mniej szkodliwymi dla materiałów niż dociskanie kart grubej księgi do kserografu, powinno być zawsze o $250 \%$ do $500 \%$ droższe niż opłaty za kserokopie.

49. Za kopiowanie należy zawsze starannie egzekwować opłaty regulaminowe, szczególnie wobec polskich emerytów i rencistów, samodzielnie utrzymujących się studentów oraz ubogich obywateli państw z byłych republik poradzieckich.

50. Skrupulatnie egzekwować inne opłaty regulaminowe, w tym znaczne sumy za kopie dla wydawnictw (szczególnie małych).

51. Archiwista winien uważać użytkownika „za wroga”, nieudacznika, „nieroba (w przeciwnym razie byłby bowiem w pracy), za potencjalnego złodzieja"'s.

52. Student to jeszcze większy wróg archiwisty.

53. Genealog to największy wróg archiwisty i sam bez upoważnienia powinien prowadzić badania tylko własnej rodziny. Genealog ma prawo również zamówić kopie metryki chrztu osoby ze sobą spokrewnionej. Gdyby jednak się zdarzyło, że księga z metrykami chrztu byłaby sporządzona bardzo trudnym i nieczytelnym pismem, i gdyby wspomniany osobnik chciał kopie kilku stron pod rząd ze wspomnianej księgi, żeby móc tę swoją jedyną metrykę poprawnie odczytać, to musi koniecznie wykazać swoje pokrewieństwo z kilkudziesięcioma osobami występującymi na wspomnianych stronach dodatkowych.

54. Archiwista nie może tolerować naukowców. Zwłaszcza oni w sposób małostkowy nadużywają praw przyznanych im w wyniku rewolucji francuskiej5.

55. Personel archiwum winien w sposób ostentacyjny zaraz przy użytkowniku skrupulatnie kontrolować kompletność i stan techniczny zdanych materiałów archiwalnych. Opisane czynności działają szczególnie sku-

\footnotetext{
4 Por. tamże, s. 22, pkt 8.

5 Por. tamże, s. 23, pkt 18.
} 
tecznie na użytkowników zasobu z wieloletnim stażem oraz na osoby wyglądające na spokojne i praworządne.

56. Należy starannie egzekwować doroczne wypełnianie formularza zgłoszenia użytkownika od osób, które od kilkudziesięciu lat zajmują się tym samym.

57. Dokładnie egzekwować kilkakrotne wypełnianie formularza zgłoszenia użytkownika od osób, które pracują nad różnymi tematami badawczymi w ciągu roku. Nie ma rzeczy ważniejszej dla archiwum niż tematy zgłoszone przez użytkownika oraz lista zespołów objętych zgłoszeniem (szczególnie wtedy, gdy jest ich bardzo dużo). Wspomnianą listę należy każdorazowo konfrontować z rewersami. W przypadku niezgodności nie udostępniać materiałów archiwalnych.

58. Stanowczo odmawiać użytkownikom wykonywania kopii ze sporządzanych $\mathrm{w}$ archiwum $\mathrm{w}$ czterech egzemplarzach inwentarzy archiwalnych. Nadmierne rozpowszechnienie inwentarzy może zwiększać liczbę użytkowników w pracowni.

59. Pod żadnym pozorem nie informować użytkownika o inwentarzach udostępnionych w Internecie. Uwaga, teraz tajemnica: jeden inwentarz można stamtąd wydrukować na domowej drukarce w dowolnej liczbie kopii.

60. Winno się zniechęcać do zamawiania materiałów archiwalnych.

61. Nie wolno użytkownikowi pokazywać regulaminu pracowni naukowej. Jeszcze ten dowie się, że za dużo mu wolno!!!

62. Należy z góry uprzedzać naiwne pytania użytkowników, mówiąc, że „tego tutaj nie ma” lub „tego tutaj się nie znajdzie”. W przypadku, gdy użytkownik jest uparty i zamówi materiały archiwalne, należy kilkakrotnie zaznaczyć, że „niczego tam nie znajdzie”. W odosobnionych przypadkach użytkownikowi można powiedzieć, że „znajdzie to”, czego szuka, $\mathrm{w}$ zaprzyjaźnionej z archiwum bibliotece lub muzeum. Odosobnionych dlatego, że tam mogą zrobić to samo i przysłać kogoś do archiwum.

63. Wielokrotnie podkreślać w pracowni naukowej, głośno i wyraźnie, wszem i wobec, fakt, że osobom nieprzygotowanym można nie udostępnić materiałów archiwalnych.

64. Z nieudawaną i nieukrywaną nieufnością traktować w pracowni archiwum przedstawicieli mniejszości wyznaniowych, byłych najeźdźców, zaborców i innych obcokrajowców. Przykłady do naśladowania: zielonoświątkowcowi oraz świadkowi Jehowy zaznaczyć, że tutaj pracują sami wierni obrońcy Maryi Panny, przy czym należy wykonywać ruchy naśladujące atak szpadą w serce niewiernego; stosownie wyglądającym ortodoksyjnym Żydom można z kolei polecić znajdującą się w pobliżu ar- 
chiwum restaurację arabską lub pyszne wyroby ze sklepu rzeźniczego nieopodal.

65. Nikt z pracowników archiwum nie powinien dać poznać po sobie, że zna jakikolwiek język kongresowy.

66. Niedopuszczalne jest tłumaczenie regulaminu pracowni na jakikolwiek język obcy. Obcokrajowiec nie może znać swoich praw.

67. Nie jest wskazane, aby w pracowni naukowej znajdowały się tłumaczenia formularza zgłoszenia użytkownika, rewersów oraz druków zamówień kopii materiałów archiwalnych. Cudzoziemiec nie powinien wiedzieć, co się wokół niego dzieje w archiwum.

68. W przypadku studentów można zauważyć, że powinni zmienić promotora pracy magisterskiej, bo ów doktor habilitowany lub profesor doktor habilitowany wykazał się znaczną niekompetencją, przysyłając swego ucznia do archiwum w nadziei, że ten coś znajdzie do swojego tematu.

69. Obecność archiwisty w pracowni nie jest obowiązkowa i zalecana. Wskazane jest, aby trudno go było znaleźć w budynku archiwum. Osoba ewentualnie pozostawiona $\mathrm{w}$ pracowni powinna być sprzątaczką, magazynierem, praktykantem, stażystą, wolontariuszem oraz zdecydowanie rzadziej przedstawicielem personelu pomocniczego, gdyż ten potrafi niekiedy udzielić fachowej informacji naukowej.

70. Unikać wyposażania archiwum w drogi monitoring. Gdy już go jednak mamy, to na równie drogie taśmy z nagraniami po trzech miesiącach lub krótszym okresie należy dokonywać kolejnych zapisów. Dobrym pomysłem jest, aby monitoring odbywał się tylko w trybie rzeczywistym, bez wykonywania kopii. Nie jest wskazane, aby ktokolwiek śledził obraz z kamer.

71. „W konsekwencji tego wszystkiego kradzież” materiałów archiwalnych „winna być ułatwiona”.

72. W zależności od istniejącego ciśnienia atmosferycznego skracać godziny funkcjonowania pracowni naukowej. W przypadku niskiego ciśnienia na 40-45 minut przed wyznaczoną godziną zamknięcia pracowni poprosić użytkowników o zdanie materiałów archiwalnych i o opuszczenie archiwum. W przypadku wysokiego ciśnienia zrobić to samo na 15-20 minut przed zamknięciem pracowni.

73. Wyrzucenie użytkownika z pracowni przyspiesza: niby to nieumyślne wyłączenie światła i uwaga: „myślałem, że nikogo tutaj nie ma, bo jest już tak późno”; przed Wigilią można zadać pytanie: „A u Pana(i), o której

6 Por. tamże, s. 22, pkt 12. 
zaczyna się kolacja wigilijna?”; personel może również otwarcie wyznać, że jest np. zmęczony, chce zamknąć pracownię i iść do domu.

74. Godziny otwarcia archiwum winny pokrywać się z godzinami pracy obywatela w wieku produkcyjnym. Ewentualne dyżury popołudniowe nie powinny odbywać się za często i należy je niespodziewanie odwoływać. Dyżury sobotnie nie powinny być praktykowane. Gdyby jednak władze archiwalne cokolwiek wymusiły na archiwum w tym zakresie, to dyżur sobotni należy zorganizować w porze, kiedy normalny obywatel śpi po ciężkim tygodniu pracy.

75. Brak dyżurów popołudniowych i sobotnich należy tłumaczyć niską frekwencją użytkowników. Ewentualne (narzucone odgórnie) próby wprowadzenia dyżurów winny być krótkotrwałe, żeby użytkownicy nie zdążyli się do nich przyzwyczaić. Nie jest wskazane tłumaczenie braku rzeczonych dyżurów względami etatowymi, gdyż archiwum może zostać spotwarzone uwagą o złej organizacji pracy.

76. Należy podtrzymać demoludową praktykę zamykania pracowni naukowej w okresie przerwy wakacyjnej w lipcu lub sierpniu albo nawet lipcu i sierpniu. Rozważa się obecnie pomysły, aby rozszerzyć przerwę wakacyjną w ogóle na lato astronomiczne.

77. Ponadto pracownia naukowa winna być również zamykana ze względu na:

- translokacje zasobu,

- zebrania pracowników,

- wystawy archiwalne,

- drzwi otwarte archiwów.

78. W archiwum nie powinno być najmniejszego kącika z krzesłami i stołem, przy którym użytkownik mógłby posilić się lub napić.

79. Żadnych ubikacji dla użytkowników7. Jeśli się to jednak nie uda - to ubikacja powinna być maksymalnie oddalona od pracowni i tylko jedna na budynek, w którym może przebywać do kilkudziesięciu osób (oczywiście, pomijając uczestników wystaw, pokazów, kursów i konferencji odbywających się w archiwum). Należy dążyć do wypracowania takiej sytuacji, aby do toalety ustawiały się kolejki. Analizowane są obecnie propozycje pobierania od korzystających z WC zróżnicowanych opłat, które pozwoliłyby zasilić skromne budżety archiwów.

80. W ubikacji należy umieścić napisy w języku polskim tłumaczone na języki kongresowe. Wspomniane napisy powinny stawiać pod znakiem zapytania kulturę osobistą i inteligencję użytkownika. Przykładowe na-

\footnotetext{
7 Por. tamże, s. 23, pkt 17.
} 
pisy: „To miejsce świadczy o Tobie. Zachowaj czystość!”; „Ten przycisk służy do spłukiwania”; „Ta szczotka służy do czyszczenia muszli klozetowej. Nie wahaj się jej użyć!”. Mniejszą czcionką należy koniecznie podać adres biura tłumaczeń, żeby nie wzbudzić podejrzeń o znajomości języków obcych w archiwum (patrz punkt 65).

81. Po zakończeniu pracy w pracowni naukowej użytkownik winien czekać 15 minut w budynku na portiera, aż ten wróci z obchodu, otworzy drzwi i umożliwi wyjście $\mathrm{z}$ archiwum.

UWAGI DODATKOWE: Szanowny Panie Profesorze, nie jestem do końca przekonany, czy w archiwum, podobnie jak w bibliotece, cały personel winien być dotknięty „ułomnościami fizycznymi” i czy idealna byłaby sytuacja, aby archiwista był osobą chromą. Przyznaję jednak, że dzięki chromym pracownikom rzeczywiście archiwum mogłoby uzyskać wydłużenie czasu potrzebnego na udostępnienie materiałów archiwalnych ${ }^{8}$. Nie wydaje mi się również słuszne, aby warto było ryzykować życie magazyniera z protezą z hakiem, który realizuje zamówienie, wyciągając archiwalia z regałów wysokiego składowania. Nie chciałbym także dostać od personelu pozbawionego kończyn górnych materiałów archiwalnych przyniesionych w zębach ${ }^{9}$. Po pierwsze, $\mathrm{w}$ archiwum przeważają materiały archiwalne o dużych formatach, po drugie, przeszkadzałaby mi ślina na archiwaliach, po trzecie, dyrekcja archiwum musiałaby z czasem refinansować pracownikom sztuczne protezy szczękowe, przez co zabrakłoby funduszy na „normalne” funkcjonowanie archiwum.

Z wyrazami szacunku Krzysztof Kopiński

\section{Letter to Umberto Eco (this is how to organise a public archives)}

Summary

The text presented is not scientific in nature but is only a pamphlet finishing with a hyperbole. This publication refers to the column of Umberto Eco: How to Organise a Public Library, that ends satirically as well. In List do U. Eco (Letter to U. Eco) some deficits of Polish archival reality have been described. The author would be very satisfied, if in all public archives some of described issues were improved. The improvement of activity of public archives does not always demand a lot of work.

8 Por. tamże, s. 23.

9 Por. tamże. 